\title{
Eupolis' Lost Taxiarchoi and the Problem of Academic Consensus
}

\author{
S. Douglas Olson
}

The nominal topic of this paper is Eupolis' Taxiarchoi, or "Taxiarchs", and in particular what, if anything, can be said of the action of the play: who the characters were, how they interacted, and what went on onstage. My real and deeper interest, however, is in how scholarly knowledge is created and maintained in regard to texts that are so emphatically "lost" that one might better say that they simply do not exist any longer. While I discuss Taxiarchoi in some detail, therefore, Eupolis' comedy is only an excuse, an opportunity to expose in a particularly clear fashion a process that goes on constantly in the field of classical studies, and indeed in any academic field devoted to making sense of the past. What I argue in what follows is that we do not and cannot really "know" anything about Taxiarchoi, at least in the way the verb "know" is conventionally and freely used; that once that point becomes clear, issues of critical methodology become more pressing than they might otherwise appear to be; and that these matters are of far greater significance than the essentially trivial question of what modern readers can agree might have gone on onstage in a lost comedy by an obscure poet over two millennia ago. But first the play itself.

Eupolis apparently began to stage dramas in $429 \mathrm{BCE}$ (thus test. 2.6), and Taxiarcho $i$ is traditionally dated to the next year, $428 \mathrm{BCE}$, on the ground that the Athenian general Phormio (PA I4958; PAA 963060), who seems to have been a central character in the action, died that summer. Dead men do not normally appear onstage in comedy, the argument goes, so we have something close to a fixed date for the play. This argument has been vigorously challenged by Ian Storey, who does his best to move Eupolis' comedy down to 4I 5 BCE, on the eve of the

This lecture was given at the Ars edendi workshop on Fragments and Commentaries 27-28 August, 2015 .

How to cite this book chapter:

Olson, S. D. 2020. Eupolis' Lost Taxiarchoi and the Problem of Academic Consensus. In: Kihlman, E. and Searby, D. (eds.). Ars Edendi Lecture Series, vol. V. Pp. I-I3. Stockholm: Stockholm University Press. DOI: https://doi.org/Io.16993/bbd.b. License: CC-BY 
Sicilian Expedition. ${ }^{\mathrm{I}}$ As I discuss this question in detail elsewhere, ${ }^{2}$ and as it does not impinge directly on my argument here, I will say nothing more about it except to observe that I believe that Storey is demonstrably wrong and that he offers the same sort of problematic claims in support of his position regarding the date of the play as those I discuss in what follows in connection with its action.

Seventeen book-fragments of Taxiarchoi are preserved, along with broken bits and pieces of a first-century CE papyrus commentary on the play (= fr. 268) first published as POxy. 2740. The title of the play is not mentioned in the papyrus. But it does refer to Phormio at one point (fr. 268.33), while at another it overlaps with one of the book-fragments (= fr. 28I), and it is universally accepted today that this is in fact a commentary on Eupolis' lost comedy. What is known of Taxiarchoi - and for most of the rest of this paper I will use the words "known" and "knowledge" within quotation marks, as it were, to describe what those of us who are interested in the text think we know - is approximately the following. According to a scholion on Aristophanes' Peace (= Taxiarchoi test. i), quoting fr. 274 , in the course of the play "Dionysus learned the customs of generals and wars at Phormio's side." Many if not all of the book-fragments can be made to fit this general theme, as I illustrate below, including the verses of Eupolis' comedy quoted as lemmata for commentary in the papyrus. The text of the papyrus is readily accessible in Kassel-Austin's edition of the comic fragments and (even easier, at least for English-speakers) in translation in Storey's Loeb edition of the so-called Old Comic poets and in Rusten's Birth of Comedy volume. ${ }^{3}$ At 175 lines long and containing substantial portions of about a dozen verses of Eupolis, the papyrus apparently treats a scene from Taxiarchoi in which Phormio taught Dionysus what it meant, in practical terms, to be an Athenian soldier. In particular, A. M. Wilson has identified what looks to be part of a rowing scene (fr. 268.48-53), in which the god - unsurprisingly — did a very bad job of one of the tasks that were set him, splashing everyone around with water and being barked at by the old military commander

I Ian C. Storey, Eupolis: Poet of Old Comedy (Oxford, 2003) 247.

2 S. Douglas Olson (ed.), Eupolis Heilotes - Chrysoun genos (frr. I47-325). Translation and Commentary (FrC 8.2: Heidelberg) 370-I.

3 Ian C. Storey (ed. and trans.), Fragments of Old Comedy Vol. II Diopeithes to Pherecrates. Loeb Classical Library 5 I4 (Cambridge Mass. and London: Harvard University Press, 20II); Jeffrey Rusten (ed.), The Birth of Comedy: Texts, Documents, and Art from Athenian Comic Competitions, 486-280 (Baltimore, 2OII). 
Phormio. ${ }^{4}$ Intriguingly, the scene appears to anticipate the action at Aristophanes' Frogs I 88-270, where Dionysus similarly does a miserable job of rowing, in this case under Charon's direction, suggesting that part of the inspiration for the latter play came from Eupolis. Finally, a vase-painting from a well-deposit in the Athenian Agora dating to around $400 \mathrm{BCE}$ and published by Crosby shows two figures, perhaps comic actors, one of them clearly labeled "Dionysus", the other "Phor-", seemingly confirming the centrality of those characters in Eupolis' comedy. ${ }^{5}$ The above can reasonably be described as the general state of contemporary knowledge about Taxiarchoi, the sort of information taken more or less for granted by those interested in the play, encoded in various ways in Kassel-Austin's edition of the fragments, and used by other scholars as a basis on which to build further, hopefully more revealing hypotheses.

Any modern evaluation of Taxiarchoi must inevitably begin with the treatment of the play by Storey, who in his 2003 monograph on Eupolis notes that in the case of Taxiarchoi we are in a relatively privileged position, at least as far as "lost" fifth-century drama goes, in that we can say "a fair bit about this comedy". ${ }^{6}$ In particular, the scholion to Peace "tells us that Dionysus went to Phormio ... to learn the rules of generals and wars", 7 on which basis Storey notes: "I am assuming that Dionysus had a major role in Taxiarchoi, that his scene with Phormion was not limited to a brief encounter in an episode." "As Storey himself observes, this is by no means a radical interpretative step, but instead represents what everyone working on the play has always done and believed, inter alia because the thesis appears to be supported by the evidence of the fragments. Storey then makes two further assumptions: first, that the Dionysus of Taxiarchoi was similar to the effeminate, clownish impostor seen in Frogs - a thesis that receives some initial, provisional support from the connections between the rowing scenes in the two comedies noted by Wilson, and that suggests that we should look for further parallels between the two plays wherever possible ${ }^{9}$ - and second, that Eupolis' chorus was firmly on Phormio's side throughout

4 A. M. Wilson, 'A Eupolidean Precedent for the Rowing Scene in Aristophanes' Frogs?', CQ NS 26 (I974), 250-252.

5 Margaret Crosby, 'Five Comic Scenes from Athens', Hesperia 24 (I955), 8I-82 with pl. 34c.

${ }^{6}$ Storey, Eupolis, p. 250.

7 Storey, Eupolis, p. 246.

8 Storey, Eupolis, p. 252.

9 Storey, Eupolis, p. 25 I-252. 
the comedy, just as the chorus of knights is firmly on the side of the Sausage-seller in Aristophanes' play of 424 BCE. ${ }^{\text {10 }}$

With this broad framework in place, Storey reconstructs an opening scene, beginning with fr. 272, which has long been thought to represent a reaction to Dionysus' arrival in camp carrying an enormous load of equipment that has no place in a soldier's life:

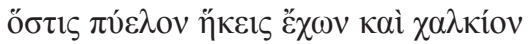

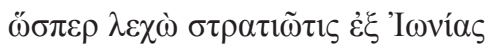

whoever you are, who have come with a bathtub and a bronze cauldron, just like a new mother from Ionia joining the ranks.

Storey observes that this "should be directed at the newly arrived Dionysus", as Kaibel for example thought, ${ }^{\mathrm{II}}$ adding "I have no problem with the attribution of these lines to Phormio himself". ${ }^{12}$ Elaborating

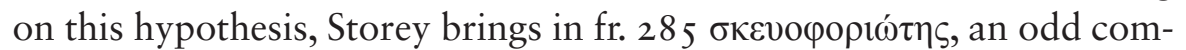

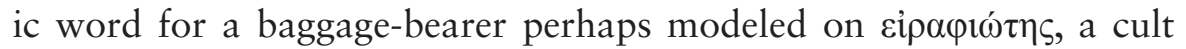
name of Dionysus himself (bHom. I.2, I 7, 20), and fr. 279 övos àkpo $\tilde{\alpha}$

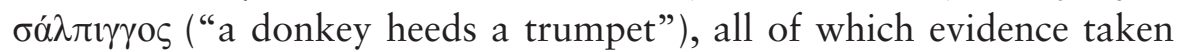
together, he suggests, may hint that "Perhaps Taxiarchoi began, like Frogs, with a comic scene involving Dionysus, his baggage, and an ass that reacted badly to the sound of the military trumpet" ${ }^{13}$ As for what Dionysus is doing in Phormio's camp in the first place, Storey notes the traditional theme of Hera's wrath on the one hand, and fr. 274

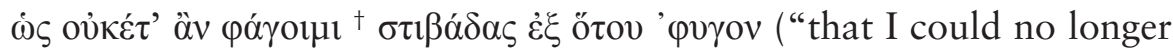
eat ${ }^{\dagger}$ since I/they fled camp-beds" — admittedly corrupt — on the other, and writes: "I wonder if in Taxiarchoi ... Dionysus entered fleeing from Hera to hide himself by joining the Athenian forces". ${ }^{\text {I4 }}$

Storey's next step toward reconstructing the action of Taxiarchoi begins with what are universally agreed to be fragments from the portion of the action in which Phormio teaches Dionysus what military life involves: fr. 276

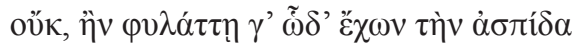

\footnotetext{
10 Storey, Eupolis, p. 250.

II ap. Kassel-Austin.

I2 Storey, Eupolis, p. 254.

${ }^{13}$ Storey, Eupolis, p. 254.

${ }^{14}$ Storey, Eupolis, p. 252.
} 
(They) won't (sc. kill you vel sim.) if you stay on guard, holding your shield like this,

where Storey notes that the line "should come from a scene of instruction in the proper use of a shield"; ${ }^{15}$ and fr. 269

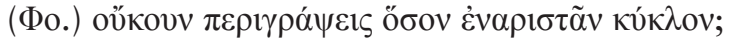

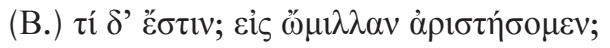

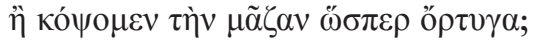

(Phormio) Draw a circle big enough to have lunch in, won't you?

(B.) What's going on? Are we going to play eis ômillan for lunch?

Or are we going to smack our barley-cake like a quail?,

where Storey, in this case following Kassel-Austin (whose version of the text is printed above; further discussion of this point below), observes: "The first speaker is Phormio ... and the other must be Dionysus". ${ }^{16}$ Storey then turns to the papyrus, first discussing a handful of verses so badly damaged that I will not treat them here, except to note that they appear to involve a discussion of military matters such as passwords (fr. 268.26-7) and soldier's pay (fr. 268.18-20). After this, Storey considers Wilson's rowing scene, fr. 268.48-53 (a combination of text and ancient commentary):

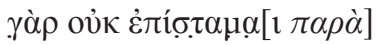

$\tau \grave{o} \pi \varepsilon \zeta \tilde{\eta} \beta \alpha \delta i \zeta \omega,[v \varepsilon \tilde{i} v]$

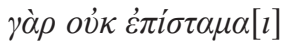

$\pi \alpha \hat{\sigma \varepsilon \varepsilon} \dot{\rho} \alpha i v \omega v \dot{\eta} \mu[\tilde{\alpha} \varsigma$, ov́k

$\pi \rho \omega ́ \rho \alpha \varsigma ; \varepsilon i \omega ́ \theta \alpha \sigma l \lambda[\dot{\varepsilon} \gamma \varepsilon l v$.

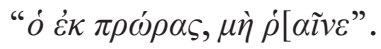

for I don't know how: alluding to the saying "I go by foot, for I don't know how to swim".

Stop sprinkling us, you toward the bow! ${ }^{17}$ They are accustomed to say:

"You toward the bow, don't get (us) wet!"

The final line of the commentary sparks a mocking comment from Storey: "One does not need to look far for an incompetent oarsman", ${ }^{18}$

${ }_{15}$ Storey, Eupolis, p. 253.

${ }^{16}$ Storey, Eupolis, p. 253.

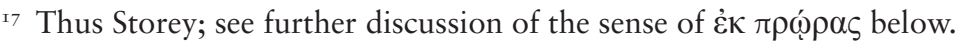

I8 Storey, Eupolis, p. 257. 
meaning that the awkward, unwarlike Dionysus is patently the incompetent rower who cannot swim.

With much of the basic plot of Taxiarchoi established, Storey goes on to reconstruct what one might call the logical next step in the dramatic action, in which Dionysus realizes that the soldier's life is not for him: fr. $27 \mathrm{I}$

Offer me Naxian almonds to chew on and wine from Naxian vines to drink!,

on which Storey comments "Meineke is surely right to attribute these lines to the god"; ${ }^{19}$ fr. 275

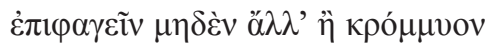

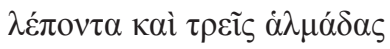

to eat nothing else, except an onion

one peels and three brined olives,

in regard to which Storey notes that this "could be either Phormio describing the lot of a soldier ... or Dionysus' own complaint about the poor quality of the food. The latter seems preferable in my judgment"; ${ }^{20}$ fr. 280

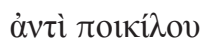

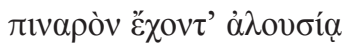

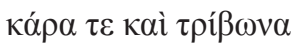

in place of an embroidered robe

having a head filthy from lack of

washing and a peasant's robe as well,

on which Storey comments: “The subject is clearly Dionysus ... I suspect Dionysus himself is speaking, complaining about his physical squalor and the state of his clothing"; ${ }^{21}$ and fr. 270

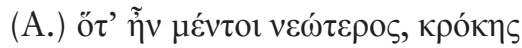

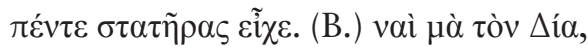

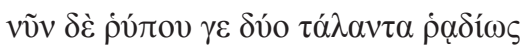

(A.) When it was newer, however, it contained

five statêres of woof-thread. (B.) Yes, by Zeus;

whereas now (it contains) two talents of dirt at least,

${ }^{19}$ Storey, Eupolis, p. 255.

20 Storey, Eupolis, p. 255.

${ }^{21}$ Storey, Eupolis, p. 255. 
in regard to which Storey says: "In view of the clear association of the krokoton with Dionysus, it is likely that Dionysus is complaining about what has happened to his garments in the course of his military training". ${ }^{22}$ In addition, Storey notes the mysterious fr. 273:

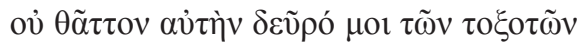

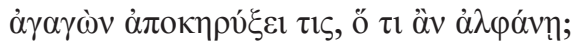

One of the bowmen bring her here quickly and auction her off for whatever price she might fetch!

on which he comments: "I wonder if this fragment does not come from a scene early in the play, where an Athenian official encounters Dionysus and his entourage and reacts accordingly", ${ }^{23}$ the point being that the god in his effeminate clothing has been mistaken for a foreign woman (to which one might compare Pentheus' threats in Euripides' Bacchae). Finally, to bring the play to a close, Storey cites a now-lost phlyax vase that depicts a male figure, perhaps equipped with a dangling comic phallus, and riding a huge fish, that comes from the same well-deposit as the Dionysus-Phormio vase and which Crosby in the original publication of both pots compared to it. Storey asks rhetorically: "I wonder if the oinochoe is showing another scene from Taxiarchoi?", and goes on to spell out his idea, which is that the pot represents the very end of Eupolis' comedy, as Dionysus - who has apparently learned how to handle a boat or the rough equivalent in the meantime - returns in triumph on the back of a giant sea-creature reminiscent of the dolphins into which the Tyrrhenian pirates are transformed at the conclusion of the Homeric Hymn in his honor. ${ }^{24}$

Storey's book has been respectfully reviewed, which is not to say that everyone who has read it has agreed with everything he has to say. ${ }^{25}$ But the treatment of the individual comedies of Eupolis has rarely been challenged directly, and the initial impression produced by Storey's handling of Taxiarchoi in particular, I suspect, is likely to be not skepticism but an astonished admiration at his ability to reassemble the plot of the play so neatly and effectively. What I argue in the rest of this paper is that Storey has in fact led us badly wrong and that the problem is not just the individual arguments and the philology on which they are

${ }_{22}$ Storey, Eupolis, p. 256.

23 Storey, Eupolis, p. 254.

24 Storey, Eupolis, p. 260.

25 See e.g. Nesselrath, review of Storey, Eupolis in Bryn Mawr Classical Review 2005.02 .44 . 
based, but his general methodological orientation, including the notion that it makes sense to talk about reconstructing lost Greek comedies as if this were a task that sufficient historical imagination and critical brilliance might allow us to accomplish.

I begin with the greatest improbability of all, which is Storey's presupposition - never stated, but clear throughout - that all the preserved fragments of Taxiarchoi can be made to fit coherently together. The problem with this assumption is that the fragments were not chosen by ancient scholars with 2 Ist-century goals in mind, which is to say that this is not a selection of material from representative and highly significant points in the action of the comedy designed to facilitate the process of reconstruction. Instead these are random bits and pieces of Eupolis' play - perhaps $2 \%$ of the original text - almost all of them chosen for quotation only because they include a rare vocabulary item, a reference to an interesting historical person or the like. The notion fundamental to Storey's project and the way he carries it out - that we can nonetheless find a likely place in the original structure of the play for almost every tiny piece of Taxiarchoi quoted for us is thus untenable, and because it is untenable, there is no point in undertaking the process - although I will qualify this argument modestly below, in what I hope is an interesting fashion. But the simple fact of the matter is that we have no hope of fully understanding the action of Taxiarchoi, and that - and this is the crucial point - the more synthetic and complete the explanation produced, the less likely it is to be correct. Storey's ingenious ability to "make everything fit" is thus the clearest sign that his reconstructions must be wrong.

Second, Storey's most basic tool for reconstructing lost comedies generally, and Taxiarchoi in particular, is analogy, combined with a readiness to fold into the argument what he takes to be related material of various sorts. Thus in the case of Taxiarchoi, if fr. 272 might be taken to represent Dionysus' arrival at Phormio's camp, and if frr. 279 and 285 can be made to fit into such a scene, and particularly if we seem to have a similar scene in Aristophanes, then on Storey's handling of the evidence we abruptly have three fragments of an initial arrival scene featuring a donkey and a porter and reminiscent of Frogs. But all of this is merely a series of unfounded guesses, each dependent on the one preceding it and lacking any solid basis in the evidence. Nor does Storey content himself with the known fragments of Taxiarchoi itself, but reaches ever further afield, by bringing in the Wrath of Hera theme, for example, to explain Dionysus' initial arrival onstage, and details 
from the Homeric Hymn to justify his vision of the end of the action, even though there is no concrete hint anywhere that any of this played a part in Eupolis' play, and above all else by whimsically appealing to the lost phlyax pot, which has no organic historical, literary or archaeological connection whatsoever to Taxiarchoi, to argue in favor of an invented thesis regarding the content of the (in fact utterly obscure) end of the play.

But perhaps the most unfortunate - although arguably also the most interesting - aspect of Storey's methodology in his handling of Eupolis' play is the combination of a readiness to guess and assert with a quiet assertion of academic and social authority. In the quotations offered above, Storey routinely informs the reader that these are merely his opinions, but seemingly not in order to make us doubt what he is saying. Instead, the rhetorical function of the language is to insist that this is what the reader too should believe, because this is what Storey believes - as I have now repeatedly pointed out, for generally insufficient reasons.

Storey's Taxiarchoi is thus a complex and unstable argumentative house of cards, which stands no chance of being an accurate account of the content of Eupolis' play, and which Storey himself acknowledges consists merely of a long string of guesses, assertions and intuitions, but which he nonetheless expects his readers to assent to and indeed build upon. Nor is this a unique case, for all Storey has done is to expand on arguments that others like Meineke and Kock made before him, pushing forward in already well-established critical directions. To illustrate concretely how this process of illusory academic consensus building works and how problematic its effects can be, I return to what we know of the Taxiarchoi papyrus, with its 176 lines of Greek text and its rowing scene.

When Lobel first published POxy. 2740 in I 968 , he printed it as two main fragments with separate numbering, accompanied by a handful of tiny scraps that seemed to be in the same hand but had been found separately, and which were therefore relegated to an appendix at the end of the volume. Whether fr. I or fr. 2 came first in the text of the commentary on Taxiarchoi was - and remains - unclear, as was and is - the size of the gap between the fragments, however arranged; perhaps it is hundreds of lines. When Austin republished the papyrus in 1973, however, he brought together all the fragments — including the stray and dubious bits in Lobel's appendix - into a single document with a single numbering system, in the arbitrary order in which Lobel 
had placed them on the page. ${ }^{26}$ That artificial creature has turned into Kassel-Austin fr. 268 of Eupolis' play and has been translated in that form - a form it never had before, certainly not in Roman Egypt, where the commentary was copied - in Storey's Loeb and the Rusten volume, which is where all but the most sophisticated modern readers will encounter it.

As for the supposed rowing scene, Storey has made Dionysus more of a land-lubber than he is, by reading more into the text than exists in lines 48-50. We know that Eupolis wrote "for I don't know how" (which is the lemma), and we know that the commentator claimed, rightly or wrongly, that this was an allusion to the saying "I go by foot, since I don't know how to swim". But we do not know that Eupolis' character said anything about swimming, for he may just as well have said e.g. "I go by ship, since I don't know how to walk". Even more to the point, a study of the uses of $\dot{\varepsilon} \kappa+$ genitive in fifth-century comedy

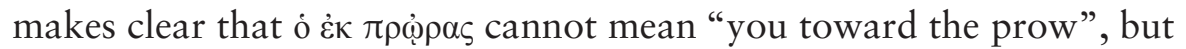
must mean instead "you on the prow", which is to say that, however water is being scattered here, figuratively or in fact, rowing is not in question, because one does not row from the prow but from the sides of a ship. To put all this more concretely: there is no 175 -line long section of papyrus commentary on Taxiarchoi, and there also appears to be no rowing-scene, meaning that there is no evidence that Eupolis' play exercised an influence on Frogs - which ought to have been regarded as a dubious argument in any case, given that Frogs is securely dated about 25 years later than Taxiarchoi. To all this one can add that we should not have expected Taxiarchoi to include a rowing scene in any case, for taxiarchs are tribal hoplite commanders rather than naval commanders, and the other fragments of the play having to do with military life all seem to be concerned with hoplite fighting. Finally and most tellingly, we do not even know that Dionysus played a central part in Eupolis' comedy. We know that he played some role in the play, which is to say that he appeared onstage at one point, learning about war from Phormio. But perhaps he merely arrived as an exemplary figure in a short scene in the second half of the action, like those that are common in Aristophanic comedies (including with divine visitors), and the more interesting point in any case is that the scholarly community has seized on the one isolated fact we have about the action of

${ }^{26}$ C. Austin (ed.), Comicorum Graecorum fragmenta in papyris reperta (Berlin and New York: De Gruyter, I973), I I3-I I 8. 
Taxiarchoi and has used it as a basis on which to reconstruct scenes, assign speakers to fragments and the like. To cite only the most obvious example of this tendency: in fr. 269 as printed above from KasselAustin and as translated by Storey and Rusten, the second speaker is identified as Dionysus. But we have no idea who the second speaker is, and Dionysus is merely a guess by Meineke that has made its way into the body of so-called "knowledge" about Eupolis' comedy.

My central point should by now be clear: Almost everything that, by general scholarly consensus today, is "known" about Taxiarchoi is not true. Better put, our "knowledge" of the play consists of a network of weakly grounded hypotheses the scholarly community has chosen to believe, and "progress" in understanding the play consists in practical terms of producing further such hypotheses - most of them better described as wild guesses or simple errors backed by rhetorical devices such as "In my opinion" - and asking others to accept them. My larger concern in this paper accordingly has less to do with Taxiarchoi than with critical methodology and the nature and significance of our enterprise. The problem with reconstructing lost comedies is not that this is a difficult business that requires ever greater ingenuity allowing for the discovery and integration of new evidence. That, at bottom, is the idea behind Storey's approach to the plays, and it is misguided as can be seen concretely from the fact that such arguments lead to consistently misleading conclusions. What we are engaged in is not a fundamentally scientific process, like e.g. discovering as much as we can about the moons of Jupiter, which are very far away and very difficult to see and understand, but about which we can gradually, provided we are clever and industrious enough, learn more and more. The problem is that Eupolis' Taxiarchoi is unlike the moons of Jupiter because Taxiarchoi does not exist. Once upon a time, it did exist. But it does not exist any longer; that is what "lost" means. This is not to say that it is pointless to discuss such texts. But the realization that we can never test our hypotheses against their object changes the nature of the enterprise entirely, and puts the focus where, I have quietly attempted to argue throughout this paper, it belongs: on critical methodology. The problem with Storey's hypotheses, for example, is in most cases not precisely that they are incorrect, for no one can tell. Perhaps Dionysus is the second speaker of fr. 269; but the question is unanswerable. The problem is instead that Storey uses what I will now freely call wrong-headed methods to reach his conclusions, and that, as part of that process, he invokes authority - his own authority and the authority of the 
scientific process - in an attempt to compel his readers into accepting his conclusions. Put another way, because we can never establish the "truth" about lost comedies (since the comedies do not exist, meaning that there is no "truth" to discover), the terms on which the scholarly debate about what remains of them proceeds can only be methodological: Are we willing to accept certain ways of handling evidence and of arguing, and to treat them as normal and appropriate? ${ }^{27}$ To do so is to render them not just normal but normative, a model for how we and our students and colleagues can and should proceed. The fundamental point of this paper is that in this case that would be a mistake, an abdication of our responsibilities as scholars and teachers.

There is a sense in which what went on Eupolis' Taxiarchoi which is to say, what we today are willing to say went on in Eupolis' Taxiarchoi - is a matter of almost complete indifference. This is a lost comedy by an obscure poet who died over 2400 years ago, and aside from the handful of classicists who will read this paper, and a few other colleagues scattered about the world, no one cares and no one needs to care. As I have tried to show, however, there is another sense in which fundamental academic and political questions are at issue in how we choose to understand this emphatically lost play, and those questions deserve our close attention and concern.

\section{Bibliography}

Austin, Colin, ed., Comicorum Graecorum fragmenta in papyris reperta (Berlin and New York: De Gruyter, 1973).

Baltussen, Han and S. Douglas Olson, 'Epilogue: A Conversation on Fragments', in Jan Kwapisz, ed., Fragments, Holes and Wholes: Reconstructing the Ancient World in Theory and Practice. Journal of Juristic Papyrology Supplement, 30 (Fundacja im. Rafała Taubenschlaga: Warsaw, 2017), pp. 393-406.

Crosby, Margaret, 'Five Comic Scenes from Athens', Hesperia 24 (I955), $76-84$.

Kassel, Rudolf, and Colin Austin, Poetae Comici Graeci, 8 vols, (Berlin and New York: De Gruyter, I983-200I).

${ }_{27}$ See in general Han Baltussen and S. Douglas Olson, 'Epilogue: A Conversation on Fragments,' in Jan Kwapisz (ed.), Fragments, Holes and Wholes: Reconstructing the Ancient World in Theory and Practice. Journal of Juristic Papyrology Supplement, 30 (Fundacja im. Rafała Taubenschlaga: Warsaw, 20I7), pp. 393-406. 
Nesselrath, Heinz-Günther, review of Storey, Eupolis in Bryn Mawr Classical Review 2005.02.44.

Olson, S. Douglas, ed., Eupolis Heilotes - Chrysoun genos (frr. I47-325). Translation and Commentary, Fragmenta Comica 8.2 (Heidelberg: Verlag Antike, 20I6).

Rusten, Jeffrey, ed., The Birth of Comedy: Texts, Documents, and Art from Athenian Comic Competitions, 486-280 (Baltimore: Johns Hopkins Press, 2OII).

Storey, Ian C., Eupolis: Poet of Old Comedy (Oxford: Oxford University Press, 2003).

Storey, Ian C., ed. and trans., Fragments of Old Comedy, Vol. II: Diopeithes to Pherecrates. Loeb Classical Library 5 I4 (Cambridge Mass. and London: Harvard University Press, 20II).

Wilson, Allan M.'A Eupolidean Precedent for the Rowing Scene in Aristophanes' Frogs?', Classical Quarterly NS 26 (I974), 250-252. 